\title{
A Novel Nanofibrous Film Chemosensor for Highly Selective and Sensitive Optical Signaling of $\mathbf{Z n}^{2+}$
}

\author{
Chen Zhou* and Heng Liu \\ Research Center for Nanotechnology, Changchun University of Science and Technology, 130022 \\ Changchun, People's Republic of China
}

\begin{abstract}
A novel nanofibrous film chemosensor was fabricated by copolymerization and electrospinning, which exhibited signaling behaviors for $\mathrm{Zn}^{2+}$. Upon addition of $\mathrm{Zn}^{2+}$, the sensor film exhibited obvious fluorescence enhancement in a linear fashion. Owing to a larger surface area and high permeability, the selectivity and sensitivity of the nanofibrous film for $\mathrm{Zn}^{2+}$ were satisfactory and achieving a limit of detection of $1.95 \times 10^{-5} \mathrm{~mol} \mathrm{~L}^{-1}$. Moreover, this material could serve as an adsorbent for $\mathrm{Zn}^{2+}$, as the adsorption capacity was $11.45 \mathrm{mg}$ of $\mathrm{Zn}^{2+}$ ions per gram of nanofibrous film.
\end{abstract}

Keywords: electrospinning, nanofibrous film, zinc ions, fluorescent sensor, adsorbent

\section{Introduction}

It is well known that $\mathrm{Zn}^{2+}$ is actively involved in numerous physiological processes, such as brain function and pathology, gene transcription, immune function and mammalian reproduction. ${ }^{1,2} \mathrm{Zn}^{2+}$ is the second most abundant transition metal ion in human body after iron, so development of metal ion chemosensors for $\mathrm{Zn}^{2+}$ has received considerable attention. ${ }^{3}$ Fluorescence detection techniques have become powerful tools for sensing and imaging of trace amounts of metal ions because of their simplicity, sensitivity and real-time monitoring with fast response time. ${ }^{4}$ Nevertheless, single fluorescent sensor molecule is not acceptable in practical application, especially in separation, removal and enrichment of target species. ${ }^{5,6}$ To introduce the solid substrate in preparing fluorescent sensor could overcome the above problem effectively. ${ }^{7}$ In order to achieve the objective, we intend to utilize electrospinning technology to fabricate nanofibrous film, which guaranteed the probes to be loaded in the solid substrate, furthermore, its porous network structure can greatly improve the diffusion velocity of interiors inside nanofibrous film. ${ }^{8}$

Electrospinning has been developed since 1934, it is an effective way for fabricating various porous composite nanofibers with high specific surface area and mechanical strength. With the development of nanotechnology,

*e-mail: zhouchen@cust.edu.cn it is increasingly concerned in many scientific fields such as chemical engineering, materials science and pharmacology. ${ }^{9-11}$ Several electrospun fibrous membrane chemosensors for specific analytes (such as metal ions, anions, poisonous gas, etc.) were designed and synthesized in recent years, which were featured with large specific surface area, high porosity and good interconnectivity. ${ }^{12-19}$ However, according to the previous literatures, nanofibrous film for sensing $\mathrm{Zn}^{2+}$ was rarely reported. So synthesize a functionalized electrospun nanofibrous film with high sensitivity and selectivity toward $\mathrm{Zn}^{2+}$ is very valuable.

Herein we reported a novel fluorescent nanofibrous film via copolymerization and electrospinning (Scheme 1). Upon addition of $\mathrm{Zn}^{2+}$, a striking fluorescence enhancement was detected. The nanofibrous film also presented very excellent affinity for $\mathrm{Zn}^{2+}$ among other metal ions, meanwhile the good adsorption of $\mathrm{Zn}^{2+}$ will expand its application prospects.

\section{Experimental}

Synthesis of 2-hydroxy-4-acryloyloxy-benzaldehyde (HAB) ${ }^{20}$

2,4-Dihydroxybenzaldehyde (1.40 g, $10 \mathrm{mmol})$, hydroquinone $(0.50 \mathrm{~g}, 4.5 \mathrm{mmol})$ and triethylamine (1.65 mL, $12 \mathrm{mmol}$ ) were dissolved in $200 \mathrm{~mL}$ 2-butanone. Then acryloyl chloride (12 mmol) in $30 \mathrm{~mL}$ 2-butanone was added dropwise into the mixture with constant stirring at $-5^{\circ} \mathrm{C}$, then increased the reaction temperature gradually to 


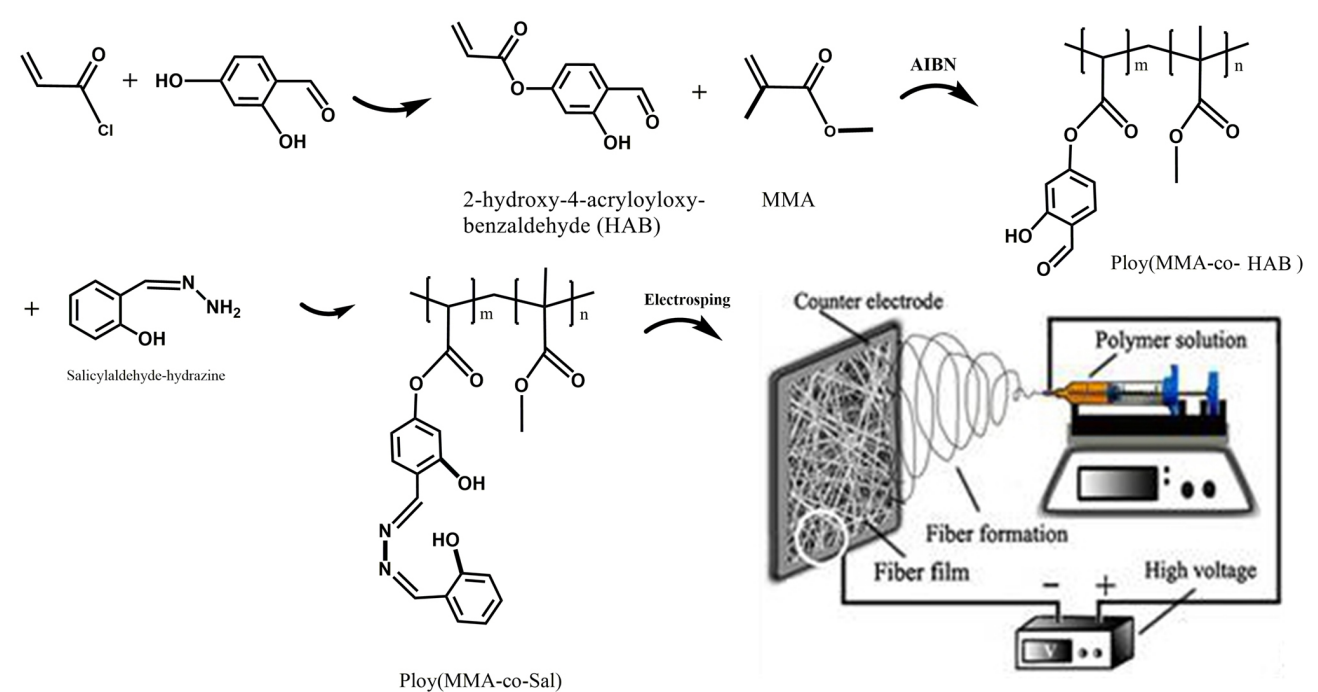

Scheme 1. Synthesis of fluorescent nanofibrous film.

room temperature $\left(25^{\circ} \mathrm{C}\right)$ and kept stirring for 2 hours until precipitate appeared. The precipitate was filtered off and dried with anhydrous sodium sulfate. The crude 2-hydroxy4-acryloyloxy-benzaldehyde (HAB) was recrystallized from ethanol. The product was collected as colorless oily liquid $1.02 \mathrm{~g}$. Yield of pure product: $52.37 \% .{ }^{1} \mathrm{H}$ nuclear magnetic resonance (NMR) $\left(300 \mathrm{MHz}, \mathrm{CDCl}_{3}\right) \delta 6.26(\mathrm{~s}, 1 \mathrm{H}$, vinyl-H), $7.00(\mathrm{~m}, 1 \mathrm{H}$, vinyl-H), $7.01(\mathrm{~m}, 1 \mathrm{H}$, vinyl- $\mathrm{H}), 7.45(\mathrm{t}, 1 \mathrm{H}$, $J 3.3 \mathrm{~Hz}, \mathrm{Ph}-\mathrm{H}), 7.62$ (d, 1H, J $3.3 \mathrm{~Hz}, \mathrm{Ph}-\mathrm{H}), 8.09$ (s, 1H, Ph-H), 9.05 (s, 1H, carbonyl-H), 11.15 (s, 1H, OH).

\section{Synthesis of salicylaldehyde-hydrazine}

Salicylaldehyde $(5.00 \mathrm{~g}, 41 \mathrm{mmol})$ in ethanol $(50 \mathrm{~mL})$ was added dropwise to the solution of hydrazine hydrate (5.00 g, $80 \mathrm{mmol})$ in ethanol at room temperature, then kept stirring for $12 \mathrm{~h}$ at room temperature. After removal of the solvent, the crude product was purified by column chromatography (silica gel, $\mathrm{CH}_{2} \mathrm{Cl}_{2} / \mathrm{EtOH}, 5: 1$ ). It was produced $3.70 \mathrm{~g}$ of white crystals. Yield of pure product: $66.38 \% .{ }^{1} \mathrm{H}$ NMR $\left(300 \mathrm{MHz}, \mathrm{CDCl}_{3}\right) \delta 1.61\left(\mathrm{~s}, 2 \mathrm{H}, \mathrm{NH}_{2}\right)$, 6.89 (m, 1H, Ph-H), 6.96 (t, 1H, J 3.6 Hz, Ph-H), 7.13 (m, 1H, Ph-H), 7.24 (m, 1H, Ph-H), 7.90 (s, 1H, Ar-H), 11.07 (s, 1H, OH).

\section{Synthesis of poly (MMA-co-HAB)}

HAB (1.90 g, $10 \mathrm{mmol})$, methyl methacrylate (MMA) $(2.00 \mathrm{~g}, 20 \mathrm{mmol})$ and AIBN $(0.02 \mathrm{~g}, 10 \mathrm{mmol})$ were dissolved in $10 \mathrm{~mL}$ DMF and introduced into a dry polymerization tube. The solution was deoxygenated by purging with $\mathrm{N}_{2}$ gas for $5 \mathrm{~min}$. The tube was sealed and placed in a regulated thermostat bath at $70{ }^{\circ} \mathrm{C}$ for $24 \mathrm{~h}$. The obtained poly (MMA-co-HAB) was transparent and colorless, then dissolved in $\mathrm{CHCl}_{3}(20 \mathrm{~mL})$ and precipitated with $\mathrm{CH}_{3} \mathrm{OH}(200 \mathrm{~mL})$. After successive dissolving and precipitation for 5 times, poly (MMA-co-HAB) was filtrated and dried under vacuum at $50{ }^{\circ} \mathrm{C}$. Yield of pure product: $2.31 \mathrm{~g}(59.23 \%)$.

\section{Synthesis of poly (MMA-co-Sal)}

Poly (MMA-co-HAB) (0.35 g) reacted with salicylaldehyde-hydrazine $(1.00 \mathrm{~g}, 7.3 \mathrm{mmol})$ in DMF $(10 \mathrm{~mL})$ at room temperature for 12 hours. The obtained poly (MMA-co-Sal) was pale yellow. It was dissolved in $\mathrm{CHCl}_{3}(20 \mathrm{~mL})$ and precipitated with $\mathrm{CH}_{3} \mathrm{OH}(200 \mathrm{~mL})$. After successive dissolving and precipitation for 4 times, the poly (MMA-co-Sal) was filtrated and dried under vacuum at $70{ }^{\circ} \mathrm{C}$. Yield of pure product: $0.73 \mathrm{~g}(54.07 \%)$. ${ }^{1} \mathrm{H} \mathrm{NMR}\left(300 \mathrm{MHz}, \mathrm{CDCl}_{3}\right) \delta 2.51$ (s, mH, CH), 3.17 (m, $3 \mathrm{nH}$, methoxy-H), 3.34 (s, $\left.2 \mathrm{H}, \mathrm{CH}_{2}\right), 4.12\left(\mathrm{~s}, 3 \mathrm{nH}, \mathrm{CH}_{3}\right)$, $6.82(\mathrm{~d}, 1 \mathrm{H}, J 3.3 \mathrm{~Hz}, \mathrm{Ph}-\mathrm{H}), 6.96$ (m, 1H, Ph-H), 6.98 (m, 1H, Ph-H), 7.00 (m, 1H, Ph-H), 7.43 (m, 1H, Ph-H), 7.70 (d, 1H, J 2.7 Hz, Ph-H), 7.96 (s, 1H, Ph-H), 9.02 (s, 2H, $\mathrm{Ar}-\mathrm{H}), 11.14$ (s, 2H, OH).

Preparation of electrospinning precursory solution and film

Poly (MMA-co-Sal) (1.00 g) was dissolved in DMF $(5.50 \mathrm{~g})$ to prepare the precursor solution with a concentration of $15.4 \mathrm{wt} . \%$, the solution was kept stirring for $24 \mathrm{~h}$ at room temperature. The generated homogenous solution was prepared for electrospinning. A syringe with an inserted wire to connect the high-voltage supply was filled with the precursor solution. The distance between syringe and receiver was $15 \mathrm{~cm}$. The high-voltage supply was fixed at $16 \mathrm{kV}$. The spinning rate was controlled 
at about $0.5 \mathrm{~mL} \mathrm{~h}^{-1}$ by the microinfusion pump. The electrospinning was performed at $25^{\circ} \mathrm{C}$.

\section{Results and Discussion}

FTIR investigations of poly (MMA-co-Sal) film

To confirm that fluorophore moiety was successfully grafted onto poly (MMA-co-HAB), Fourier transformed infrared spectroscopy (FTIR) was used. Figure 1 exhibited the FTIR spectra of (A) monomer HAB, (B) salicylaldehyde-hydrazine, (C) poly (MMA-co-HAB) and (D) poly (MMA-co-Sal) film. The characteristic bands of (A) and (C) at $1740 \mathrm{~cm}^{-1}$ (aldehyde $\mathrm{C}=\mathrm{O}$ ) confirmed that aldehyde groups of $\mathrm{HAB}$ were successfully introduced into poly (MMA-co-HAB). But this band did not present in the spectra of (D), indicating that aldehyde and salicylaldehydehydrazine generated Schiff base salicylaldehyde-hydrazine structure in the poly (MMA-co-Sal) film. Simultaneously, (B) and (D) exhibited a strong band at $1630 \mathrm{~cm}^{-1}$, which was ascribed to $\mathrm{C}=\mathrm{N}$ in the salicylaldehyde-hydrazine molecule. It was worth noting that the band of (D) at $1720 \mathrm{~cm}^{-1}$ might be ascribed to $\mathrm{N}-\mathrm{N}$ in the hydrazine molecule. Therefore, we confirmed that salicylaldehyde-hydrazine group was successfully introduced into the nanofibrous film.

\section{Morphologies of poly (MMA-co-Sal) nanofibers}

Figure 2 shows the typical scanning electron microscope (SEM) images of the poly (MMA-co-Sal) nanofibrous film under different scales. It can be found that the poly (MMA-co-Sal) film was composed of numerous, randomly oriented nanofibers. The surface of the poly (MMA-co-Sal) (15 wt.\%) nanofibrous film did not show any serious cracks or degradation under the optimized conditions. The average diameter (D) of nanofibers can be estimated in the following equation:

$\mathrm{D}=\frac{1}{\mathrm{n}} \sum_{\mathrm{i}=1}^{\mathrm{n}} \mathrm{X}_{\mathrm{i}}^{*} \frac{\mathrm{B}}{\mathrm{L}}$

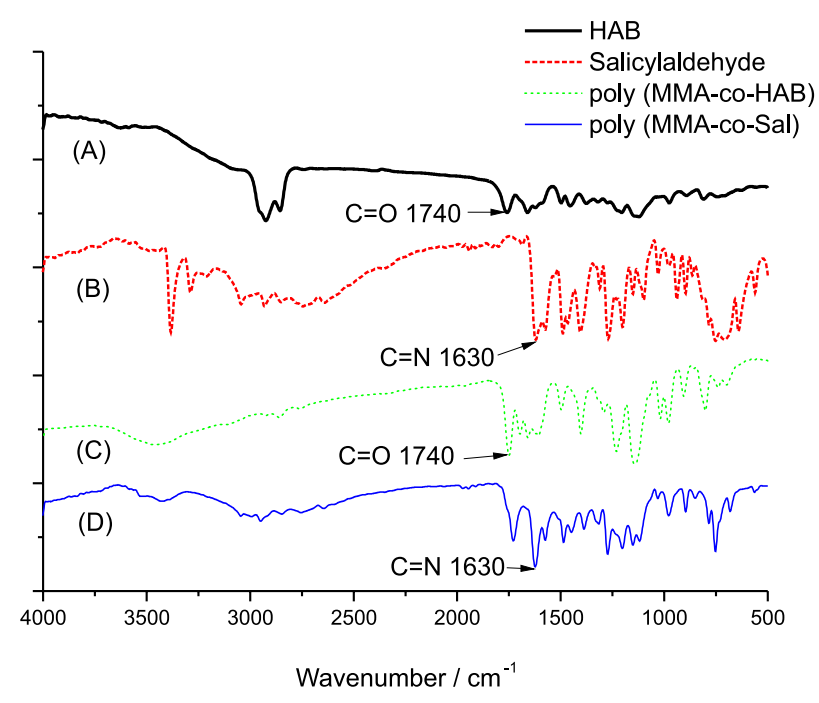

Figure 1. FTIR spectra of (A) HAB; (B) salicylaldehyde; (C) poly (MMA-co-HAB); (D) poly (MMA-co-Sal).

where $\mathrm{n}$ stands for the number of the nanofibers in SEM images, $\mathrm{X}$ stands for the diameter of each nanofiber, B is the scale bar, and $\mathrm{L}$ refers to the length of the scale bar. Therefore, the average diameter of poly (MMAco-Sal) nanofibers is $1.26 \mu \mathrm{m}$ as analyzed from SEM images (Figure 2b). This network structure of electrospun film provides a surface area-to-volume ratio roughly 1 to 2 orders of magnitude higher than that of known continuous thin films. ${ }^{21}$ This unique porous structure could greatly accelerate the targets to diffuse close to the sensing elements and increase the complexation efficiency. ${ }^{22}$

Response of poly (MMA-co-Sal) nanofibrous film to $\mathrm{Zn}^{2+}$ ions

With the synthesis complete, the optical property of the poly (MMA-co-Sal) nanofibrous film in the presence of $\mathrm{Zn}^{2+}$ was investigated. Evidence for ion interaction with the nanofibrous film was first sought using fluorescence spectroscopy, the fluorescence titration experiments were conducted under the condition of acetonitrile-Tris buffer solution at $\mathrm{pH}$ 7.1. The poly (MMA-co-Sal) nanofibrous

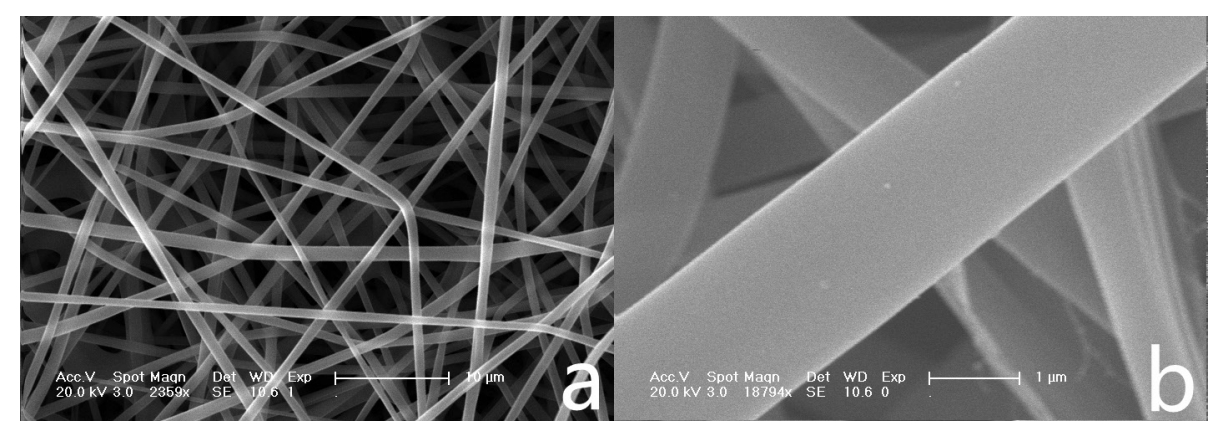

Figure 2. SEM image of poly (MMA-co-Sal) nanofibers. 
film alone did not exhibit fluorescence at $504 \mathrm{~nm}$ [ $\mathrm{V}\left(\mathrm{CH}_{3} \mathrm{CN}\right): \mathrm{V}\left(\mathrm{H}_{2} \mathrm{O}\right), 9: 1, \mathrm{pH} 7.1$, excited at $\left.400 \mathrm{~nm}\right]$. The fluorescence intensity gradually enhanced upon the addition of $\mathrm{Zn}^{2+}$ from 0 to $200 \mu \mathrm{mol} \mathrm{L} \mathrm{L}^{-1}$, this "switch-on" process could be observed under the irradiation of ultraviolet lamp (Figure 3). The increasing fluorescence intensity of the nanofibrous film depending on the concentration of $\mathrm{Zn}^{2+}$ was in a linear manner as illustrated in Figure 4 $(\mathrm{R}=0.99255)$, which indicated that poly (MMA-co-Sal) nanofibrous film had potential application for quantitative determination of $\mathrm{Zn}^{2+}$, and the limit of detection (LOD) could reach to $1.95 \times 10^{-5} \mathrm{~mol} \mathrm{~L}^{-1}$ by calculation from this linear relationship (based on $\mathrm{LOD}=\mathrm{KSb}_{1} / \mathrm{S}$, where $\mathrm{K}=3$; $\mathrm{Sb}_{1}$ is the standard deviation of the blank solution; $\mathrm{S}$ is the slope of the calibration curve).

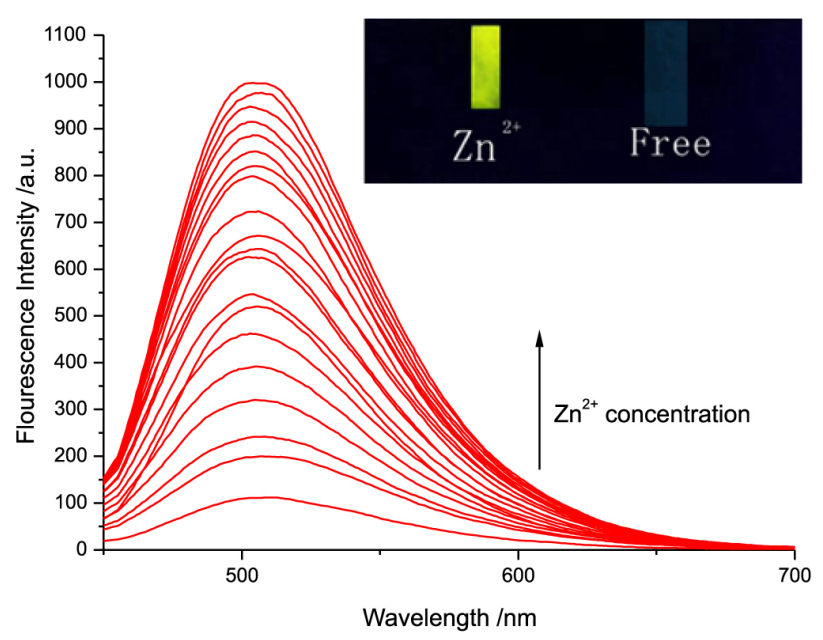

Figure 3. Fluorescent emission spectra of the nanofibrous film in the presence of $\mathrm{Zn}^{2+}\left(0-200 \mu \mathrm{mol} \mathrm{L} \mathrm{L}^{-1}\right)$ at different concentrations in acetonitrile-water solution $(9: 1, \mathrm{v} / \mathrm{v}, 0.1 \mathrm{M}$ Tris- $\mathrm{HCl}$ buffer at $\mathrm{pH} 7.10)$ $(\lambda \mathrm{ex}=400 \mathrm{~nm}, \lambda \mathrm{em}=504 \mathrm{~nm})$.

\section{Selective and competitive experiments}

To gain insight into the selectivity of the fluorometric behavior of poly (MMA-co-Sal) nanofibrous film for $\mathrm{Zn}^{2+}$, various common metal ions in environmental and biological interest were introduced to investigate their impact on the fluorescence response of poly (MMA-co-Sal). In selectivity experiments the fluorometric behavior of poly (MMA-co-Sal) was investigated upon addition of several metal ions such as $\mathrm{K}^{+}, \mathrm{Al}^{3+}, \mathrm{Ni}^{2+}, \mathrm{Ca}^{2+}, \mathrm{Mg}^{2+}, \mathrm{Mn}^{2+}$, $\mathrm{Fe}^{3+}, \mathrm{Cd}^{2+}, \mathrm{Pb}^{2+}, \mathrm{Hg}^{2+}, \mathrm{Cr}^{3+}, \mathrm{Cu}^{2+}, \mathrm{Co}^{2+}\left(100 \mu \mathrm{mol} \mathrm{L}{ }^{-1}\right)$ in acetonitrile-Tris buffer solution [ $\mathrm{V}\left(\mathrm{CH}_{3} \mathrm{CN}\right): \mathrm{V}\left(\mathrm{H}_{2} \mathrm{O}\right), 9: 1$, $\mathrm{pH} 7.1$, excited at $400 \mathrm{~nm}$ ]. As shown in Figure 5 (black bar), only $\mathrm{Zn}^{2+}$ to the nanofibrous film caused a remarkable fluorescence enhancement at $504 \mathrm{~nm}$ in the emission spectra, the introduction of other metal ions of $\mathrm{K}^{+}, \mathrm{Al}^{3+}$, $\mathrm{Ni}^{2+}, \mathrm{Ca}^{2+}, \mathrm{Mg}^{2+}, \mathrm{Mn}^{2+}, \mathrm{Fe}^{3+}, \mathrm{Cd}^{2+}, \mathrm{Pb}^{2+}, \mathrm{Hg}^{2+}, \mathrm{Cr}^{3+}, \mathrm{Cu}^{2+}$,

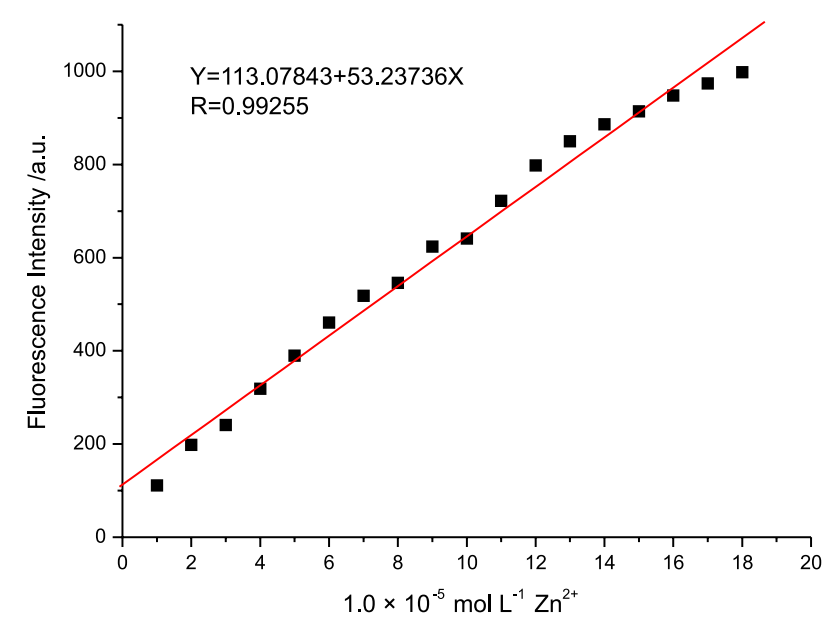

Figure 4. Normalized response of the fluorescent signal to changing $\mathrm{Zn}^{2+}$ $(0-200 \mu \mathrm{mol} \mathrm{L}-1)$ concentrations $(\lambda \mathrm{ex}=400 \mathrm{~nm}, \lambda \mathrm{em}=504 \mathrm{~nm})$.

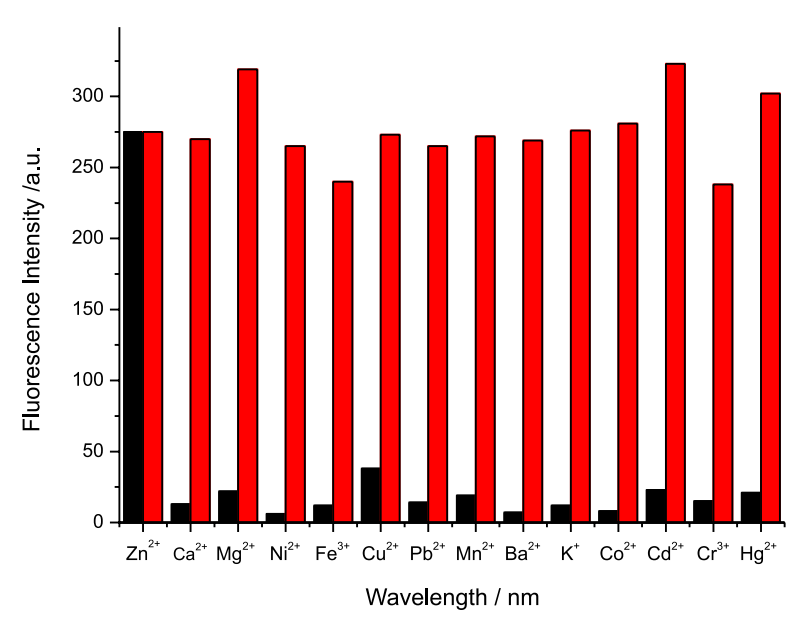

Figure 5. Fluorescent response of the film in selectivity experiment (black bar) and competition experiment (red bar) in acetonitrile-water solution $(9: 1, \mathrm{v} / \mathrm{v}, 0.1 \mathrm{M}$ Tris-HCl buffer at pH 7.10) $(\lambda \mathrm{ex}=400 \mathrm{~nm}, \lambda \mathrm{em}=504 \mathrm{~nm})$.

$\mathrm{Co}^{2+}$ slightly affected the fluorescence. So it was clearly indicated that our proposed nanofibrous film exhibited high selectivity to $\mathrm{Zn}^{2+}$ ions. In order to further test the interference of other common cations in the determination of $\mathrm{Zn}^{2+}$, the competition experiments were performed: the nanofibrous film were conducted with $30 \mu \mathrm{mol} \mathrm{L} \mathrm{L}^{-1}$ $\mathrm{Zn}^{2+}$ to induce fluorescence enhancement before mixing $300 \mu \mathrm{mol} \mathrm{L}{ }^{-1} \mathrm{~K}^{+}, \mathrm{Al}^{3+}, \mathrm{Ni}^{2+}, \mathrm{Ca}^{2+}, \mathrm{Mg}^{2+}, \mathrm{Mn}^{2+}, \mathrm{Fe}^{3+}, \mathrm{Cd}^{2+}$, $\mathrm{Pb}^{2+}, \mathrm{Hg}^{2+}, \mathrm{Cr}^{3+}, \mathrm{Cu}^{2+}, \mathrm{Co}^{2+}$. The fluorescence intensity of the mixed system at $504 \mathrm{~nm}$ is shown in Figure 5 (red bar), all of the fluorescence intensity exhibited still enhancement, so the experimental results indicated that these ions showed no obvious interference for detecting $\mathrm{Zn}^{2+}$ in the fluorescence change at $504 \mathrm{~nm}$. Thus the fluorometric analysis above had proven that poly (MMA$c o$-Sal) nanofibrous film could serve as an outstanding sensitive and selective fluorescent sensor for $\mathrm{Zn}^{2+}$ in our prospective. 
Adsorption kinetics of $\mathrm{Zn}^{2+}$ ions onto poly (MMA-co-Sal) nanofibrous film

The adsorption and separation of $\mathrm{Zn}^{2+}$ was rarely reported in previous studies about $\mathrm{Zn}^{2+}$ sensors. So in this work, we comparative-deeply discussed the adsorptive and separable properties of poly (MMA-co-Sal) nanofibrous film in removing $\mathrm{Zn}^{2+}$ ions from solution. The nanofibrous film was cut to the size of $1.0 \times 2.5 \mathrm{~cm}$ (about $8.97 \mathrm{mg}$ in weight), and it was taken into the aqueous solution in various concentrations of $\mathrm{Zn}^{2+}$ for 24 hours. ${ }^{23}$ The relationship between equilibrium adsorption amounts and equilibrium concentrations was demonstrated in Figure 6a. It was clearly depicted that the adsorption increased significantly with the increase in $\mathrm{Zn}^{2+}$ concentration until the saturation concentration $\left(100 \mathrm{mg} \mathrm{L}^{-1}\right)$. As was illustrated in Scheme 2, the initial increase in $\mathrm{Zn}^{2+}$ adsorption was due to the unsaturated chelating sites being gradually occupied with the increasing $\mathrm{Zn}^{2+}$ concentration, when the chelating sites
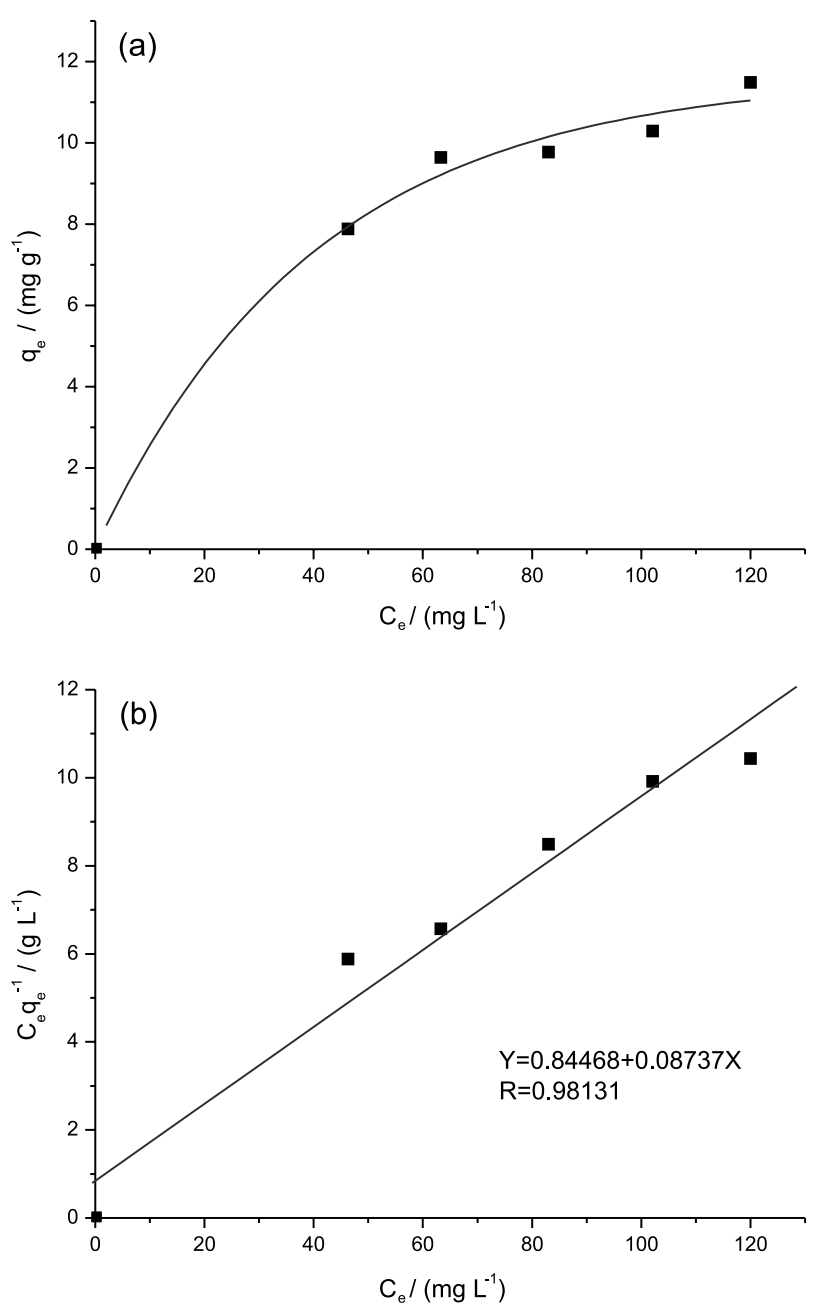

Figure 6. (a) Adsorption isotherm and (b) Langmuir plot of $\mathrm{Zn}^{2+}$ on the poly (MMA-co-Sal) nanofibrous film.

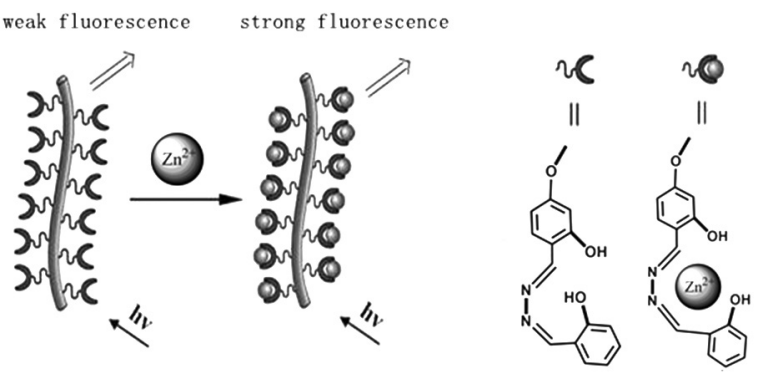

Scheme 2. Schematic illustration for preparation of poly (MMA-coSal) nanofiber fluorescent sensors by electrospinning for $\mathrm{Zn}^{2+}$ ions with enhanced detection sensitivity.

became saturated, the equilibrium adsorption amounts leveled off as well. ${ }^{24}$ The concentration of $\mathrm{Zn}^{2+}$ left in aqueous solution was inspected by inductively coupled plasma mass spectrometry (ICP-MS). The Langmuir adsorption equation was given to analyze experimental adsorption equilibrium data of $\mathrm{Zn}^{2+}: 25$

$\frac{\mathrm{C}_{\mathrm{e}}}{\mathrm{q}_{\mathrm{e}}}=\frac{1}{\mathrm{~K}_{\mathrm{L}} \mathrm{q}_{\mathrm{m}}}+\frac{\mathrm{C}_{\mathrm{e}}}{\mathrm{q}_{\mathrm{m}}}$

where $\mathrm{q}_{\mathrm{e}}$ is the equilibrium quantity of the metals ions adsorbed onto poly (MMA-co-Sal) nanofibrous film $\left(\mathrm{mg} \mathrm{g}^{-1}\right), \mathrm{C}_{\mathrm{e}}$ is the equilibrium concentration $\left(\mathrm{mg} \mathrm{L}^{-1}\right)$, $\mathrm{q}_{\mathrm{m}}\left(\mathrm{mg} \mathrm{g}^{-1}\right)$ and $\mathrm{K}_{\mathrm{L}}\left(\mathrm{L} \mathrm{mg}^{-1}\right)$ are the Langmuir constants related to the saturation adsorption capacity and binding energy, respectively. ${ }^{26}$ As was shown in Figure 6b, the Langmuir $\mathrm{C}_{\mathrm{e}} \mathrm{q}_{\mathrm{e}}^{-1}$ versus $\mathrm{C}_{\mathrm{e}}$ plot was in a good linear relationship $\left(R^{2}>0.98\right)$. Based on the assumption of the Langmuir theory that adsorption occurs at particular homogeneous sites within the adsorbent, this implies that one chelating sites is occupied by one metal ion exclusively, then no further adsorption occurs at that location. Thus, the adsorption that happened on the poly (MMA-co-Sal) nanofibrous film was monolayer. ${ }^{27,28}$ The linear fit of the $\mathrm{C}_{\mathrm{e}} \mathrm{q}_{\mathrm{e}}^{-1}$ versus $\mathrm{C}_{\mathrm{e}}$ plot was illustrated in Figure $6 \mathrm{~b}$, relevant data indicated that $\mathrm{Zn}^{2+}$ ion adsorption accorded with the Langmuir isotherm, and the values of $\mathrm{K}_{\mathrm{L}}$ and $\mathrm{q}_{\mathrm{m}}$ in Table 1 were calculated from the equation in Figure 6b. The adsorption capacity was $11.45 \mathrm{mg}$ of $\mathrm{Zn}^{2+}$ ions per gram of poly (MMA-co-Sal) nanofibrous film (Table 1).

Table 1. The Langmuir constants for $\mathrm{Zn}^{2+}$ on poly (MMA-co-Sal) nanofibrous film

\begin{tabular}{lccc}
\hline Metal ion & $\mathrm{K}_{\mathrm{L}} /\left(\mathrm{L} \mathrm{mg}^{-1}\right)$ & $\mathrm{q}_{\mathrm{m}} /\left(\mathrm{mg} \mathrm{g}^{-1}\right)$ & $\mathrm{R}^{2}$ \\
\hline $\mathrm{Zn}^{2+}$ & 0.135 & 11.45 & 0.98131 \\
\hline
\end{tabular}

$\mathrm{K}_{\mathrm{L}}$ : related to the binding energy; $\mathrm{q}_{\mathrm{m}}$ : related to the saturation adsorption capacity. 


\section{Conclusions}

In conclusion, we synthesized a novel fluorescent nanofibrous film for sensing and adsorbing $\mathrm{Zn}^{2+}$ with high selectivity and sensitivity. The limit of detection of the nanofibrous film for $\mathrm{Zn}^{2+}$ was calculated to be $1.95 \times 10^{-5} \mathrm{~mol} \mathrm{~L}^{-1}$. Moreover, the adsorption capacity was about $11.45 \mathrm{mg}$ of $\mathrm{Zn}^{2+}$ ions per gram of the nanofibrous film. So we expect that our sensing material to be a prospect in biomedical and environmental applications for the detection of $\mathrm{Zn}^{2+}$ in the future.

\section{Supplementary Information}

Supplementary information is available free of charge at http://jbcs.sbq.org.br as a PDF file.

\section{Acknowledgments}

The authors gratefully acknowledge the support of the Youth Science Foundation of Changchun University of Science and Technology (XQNJJ-2016-11) and the Natural Science Foundation of Inner Mongolia (No. 2015BS0202).

\section{References}

1. Fraker, P. J.; King, L. E.; Annu. Rev. Nutr. 2004, 24, 277.

2. Xu, Z.; Chem. Commun. 2012, 48, 4764.

3. Silva, A. P.; Gunaratne, H. Q.; Gunnlaugsson, T.; Huxley, A. J. M.; McCoy, C. P.; Rademacher, J. T.; Rice, T. E.; Chem. Rev. 1997, 97, 1515 .

4. Tarkeshwar, G.; Anup, K.; Analyst 2011, 136, 4127.

5. Ito, H.; Matsuoka, M.; Ueda, Y.; Takuma, M.; Kudo, Y.; Lguchi, K.; Tetrahedron 2009, 65, 4235.

6. Kim, Y. R.; Kim, H. J.; Kim, J. S.; Kim, J. S.; Kim, H.; Adv. Mater. 2008, 20, 4428.

7. Wang, W.; Li, Y. P.; Sun, M. D.; Zhou, C.; Zhang, Y.; Li, Y. X.; Yang, Q. B.; Chem. Commun. 2012, 48, 6040.

8. Doshi, J.; Reneker, D. H.; J. Electrost. 1993, 35, 151.
9. Sun, L.; Yu, X.; Sun, M. D.; Wang, H. G.; Xu, S. F.; Dixon, J. D.; Wang, Y. A.; Li, Y. X.; Yang, Q. B.; Xu, X. Y.; J. Colloid Interface Sci. 2011, 358, 73.

10. Reneker, D.; Yarin, A.; Fong, H.; Koombhongse, S.; J. Appl. Phys. 2000, 87, 4531.

11. Shin, Y.; Hohman, M.; Brenner, M.; Rutledge, G.; Polymer 2001, 42, 9955.

12. Wang, X.; Drew, C.; Lee, S. H.; Senecal, K. J.; Kumar, J.; Samuelson, L. A.; Nano Lett. 2002, 2, 1273.

13. Onguna, M. Z.; Ertekin, K.; Gocmenturka, M.; Ergun, Y.; Suslu, A.; Spectrochim. Acta, Part A 2012, 90, 177.

14. Zhang, Y.; He, X.; Li, J.; Miao, Z.; Huang, F.; Sens. Actuators, B 2008, 132, 67.

15. Ding, B.; Yamazaki, M.; Shiratori, S.; Sens. Actuators, B 2005, 106, 477 .

16. Zhou, C.; Xiao, N.; Li, Y. P.; Can. J. Chem. 2014, 92, 1092.

17. Song, X.; Liu, L.; Sens. Actuators, A 2009, 154, 175.

18. Nezhadali, A; Es'haghi, Z.; Bahar, S.; Banaei, A.; Shiran, J. A.; J. Braz. Chem. Soc. 2016, 27, 99.

19. Wang, X.; Ding, B.; Sun, M.; Yu, J.; Sun, G.; Sens. Actuators, B 2010, 144, 11 .

20. Wang, W.; Wang, X. L.; Yang, Q. B.; Fei, X. L.; Sun, M. D.; Song, Y.; Chem. Commun. 2013, 49, 4833.

21. Wang, X.; Drew, C.; Lee, S. H.; Senecal, K. J.; Kumar, J.; Samuelson, L. A.; Nano Lett. 2002, 11, 1273.

22. Wang, W.; Wang, X. L.; Yang, Q. B.; Fei, X. L.; Sun, M. D.; Song, Y.; Chem. Commun. 2013, 49, 4833.

23. Haider, S.; Park, S. Y.; J. Membr. Sci. 2009, 328, 90.

24. Ramazan, C.; Cengiz, S.; Mehmet, S.; Sep. Purif. Technol. 2006, 49, 107.

25. Saeed, K.; Haider, S.; Oh, T. J.; Park, S. Y.; Membr. Sci. 2008 , 322,400

26. Deng, S.; Bai, R.; J. Colloid Interface Sci. 2003, 260, 265.

27. He, Z. Y.; Nie, H. L.; White, C. B.; Bioresour. Technol. 2008, 99, 7954

28. Hsu, T. C.; J. Hazard. Mater. 2009, 171, 995.

Submitted: December 22, 2016

Published online: February 20, 2017 